\title{
Correction to: Anakinra in Still's disease: a profile of its use
}

\section{Katherine A. Lyseng-Williamson ${ }^{1}$}

Published online: 17 November 2018

c) Springer Nature 2018

\section{Correction to: Drugs \& Therapy Perspectives https://doi.org/10.1007/s40267-018-0572-5}

The article Anakinra in Still's disease: a profile of its use, written by Katherine A. Lyseng-Williamson, was originally published Online First without open access. After publication online, Swedish Orphan Biovitrum AB requested that the article be Open Choice to make the article an open access publication. Post-publication open access was funded by Swedish Orphan Biovitrum AB. The article is forthwith distributed under the terms of the Creative Commons Attribution-NonCommercial 4.0 International License (http:// creativecommons.org/licenses/by-nc/4.0/), which permits any noncommercial use, duplication, adaptation, distribution and reproduction in any medium or format, as long as you give appropriate credit to the original author(s) and the source, provide a link to the Creative Commons license and indicate if changes were made.

The original article can be found online at https://doi.org/10.1007/ s40267-018-0572-5.

Katherine A. Lyseng-Williamson

dtp@springer.com

1 Springer, Private Bag 65901, Mairangi Bay, 0754 Auckland, New Zealand
The original article has been corrected.

Open Access This article is distributed under the terms of the Creative Commons Attribution-NonCommercial 4.0 International License (http://creativecommons.org/licenses/by-nc/4.0/), which permits any noncommercial use, distribution, and reproduction in any medium, provided you give appropriate credit to the original author(s) and the source, provide a link to the Creative Commons license, and indicate if changes were made. 